\title{
Survey of Gross Alpha Radioactivity in Bore Hole and Well Water in Sokoto City North-Western Nigeria
}

\author{
${ }^{* 1}$ A.Saidu and ${ }^{2} E$.E. Ike \\ 1Department of Physics Usmanu Danfodiyo University, Sokoto, Nigeria \\ 2Department of Physics University of Jos, Nigeria \\ [Corresponding Author: Email: amsa_koko@yahoo.com; 第: +234(0)7063538383]
}

\begin{abstract}
A survey of the gross alpha radioactivity in drinking water from wells and bore holes in Sokoto city was carried out. Forty samples were drawn at random from locally dug wells and bore holes in Sokoto city, Northern Nigeria. The samples were analyzed using the Eurysis system- eight channel gas filled proportional counter. The result shows that the range of alpha activity varied from 0.01 to $6.00 \mathrm{~Bq} / \mathrm{L}$, with a geometric mean of $0.26 \mathrm{~Bq} / \mathrm{L}$. Seventy five percent (75\%) and $25 \%$ of alpha activity were respectively below and above the USEPA contaminant limit of $0.55 \mathrm{~Bq} / \mathrm{L}$ radioactivity in water. Thirty two and half percent $(32.5 \%)$ and $67.5 \%$ of the alpha activity were respectively below and above the contaminant limit of $0.5 \mathrm{~Bq} / \mathrm{L}$, as set out by $\mathrm{WHO}$. The gross alpha effective dose was $0.068 \mathrm{msv} / \mathrm{y}$ (WHO range is $0.04-0.1 \mathrm{mSv} / \mathrm{y}$ ).

Keywords: Gross alpha, activity, contaminant limit, Effective dose, geometric mean.
\end{abstract}

\section{INTRODUCTION}

Water is one of the most important natural resources and demand for it is on the increase. Skillful management of water body is therefore required if it is to be used for diverse purposes (Habila, 2008). About $95 \%$ of all fresh water on earth is ground water found in natural rock formations (Brassard, 1996).

Water pollution is the contamination of the water bodies such as lakes, rivers, ocean and underground water by human or natural activities which can be harmful to organisms and plants (Krantz and Kifferstein, 2009). Many causes of water pollution include: sewage, nitrates and phosphates fertilizers, petroleum and refinery wastes, mining wastes, radioactive substances and toxic chemicals. Ground water pollution is much more difficult to abate than surface water pollution because ground water can move great distances through unseen aquifers (Daniel, 2006). Water pollution is the major problem globally. According to Larry (2006), water pollution is the leading worldwide cause of death and diseases, and that it accounts for the deaths of more than 14,000 people daily. Estimate also suggested that 1.5 billion people lack safe drinking water and that at least 5 million deaths per year can be attributed to waterborne diseases (Krantz and Kifferstein, 2009).

Most of the sources of water supply in Nigeria are upland surface water or groundwater from boreholes and hand dug wells. The earth's crust contain naturally occurring radioactive materials (terrestrial radioactivity), which increases with depth (Kozinski, 1995). These radioactive materials occur naturally and of most concern are the uranium series, thorium series and their progeny (radon and thoron). Because of this, drinking water from deep wells and boreholes are likely to contain a higher concentration of radioactive elements than surface water (Tajudeen, 2006). Spring or flowing water, passes through rocks that contain many radioactive materials and it could be transported into wells, boreholes and taps water through burst pipes. Important radionuclides in drinking water are tritium, potassium-40, radium and radon, which are alpha beta and gamma emitters (Tajudeen, 2006).

Not much work has been done on measurement of radioactivity in water in Nigeria. Onoja (2004) determined gross alpha activity in well water from Zaria area and reported geometric mean values of $6.32 \mathrm{~Bq} / \mathrm{m}^{3}$ for alpha activity. Tajudeen (2006) from work in Gwammaja area of Kano metropolitan city reported geometric mean values of $3.99 \mathrm{~Bq} / \mathrm{m}^{3}$ for alpha activity. Habila (2008) surveyed the gross alpha radioactivity in wells and boreholes from Jos city and reported alpha activity of 0.1 to $6.05 \mathrm{~Bq} / \mathrm{L}$, with a geometric mean of $0.68 \mathrm{~Bq} / \mathrm{L}$. These are far below the contaminant limits of radioactivity in drinking water, as set by the 1976 National interim regulations USEPA of $500 \mathrm{~Bq} / \mathrm{m}^{3}$ for alpha and WHO which is $0.10 \mathrm{~Bq} / \mathrm{L}$ for alpha. Avwiri and Agbalagba (2007) surveyed gross alpha radionulide activity in Okpare-Creek Delta State and reported mean alpha activity of $5.07 \mathrm{~Bq} / \mathrm{L}$. Their overall results show 
activities below practical screening level if not that of Jos and Okpare-Creek.

There is evidence from both human and animal studies that radiation exposure may increase the long term incidence of cancer and that the rate of genetic malformations may be increased by radiation exposure (Otton, 1994). It is therefore important to determine the amount of radioactivity in drinking water available so as to guard against its health hazards.

The process of identifying individual radioactive species and determining their concentration requires sophisticated and expensive analysis, which is normally not justified, because the concentrations of radionuclides in most circumstances are very low. A more practical approach is to use a screening procedure, where the total radioactivity present in the form of alpha and beta radiation is first determined, without regard to the identity of specific radionuclides (WHO, 2006).

Screening levels for drinking-water below which no further action is required are

$0.5 \mathrm{~Bq} /$ litre for gross alpha activity and $1 \mathrm{~Bq} /$ litre for gross beta activity. The screening level for gross alpha activity is $0.5 \mathrm{~Bq} /$ /itre (instead of the former $0.1 \mathrm{~Bq} /$ litre), as this activity concentration reflects values nearer the radionuclide-specific guidance RDL (WHO, 2008). This paper presents alpha activity in $\mathrm{Bq} / \mathrm{L}$ for water from boreholes and wells from Sokoto city, as compared to USEPA maximum contaminant limit of $0.55 \mathrm{~Bq} / \mathrm{L}$ and WHO maximum contaminant limit of $0.5 \mathrm{Bg} / \mathrm{L}$. These results will therefore form a base-line data of radioactivity in drinking water for the Sokoto city.

\section{Geography and Geology of the Study Area}

Sokoto is a city located in the extreme northwest of Nigeria near to the confluence of River Sokoto and the River Rima. Its geographical coordinates are longitude $12^{\circ} 55^{\prime} 02^{\prime \prime} \mathrm{N}$, and $13^{0} 10^{\prime} 05^{\prime \prime} \mathrm{N}$ and latitude $5^{\circ} 09^{\prime} 18^{\prime \prime} \mathrm{E}$ and $5017 / 24 / / E$. The city has a population of about 583,039 with an average population density of about 300 people per square kilometer (NBSN, 2010). The Sokoto Basin is Nigeria sector of extensive lullemmeden Basin. It predominantly consists of a gently undulating plain with elevation varying from 250 to 400 meters above sea level. The area is marked by high drainage density stream dissection resulting in deeply incised ravines. The major stratigraphic subdivisions recognized (Figure 1) are: continental deposits of Upper Eocene Miocene age (Gwandu Formation), intermediate marine and brackish water deposits, Sokoto Group [Paleocene] (Kalambina Formation, Dange Formation, Wurno Formation, Dukamaje Formation, Taloka Formation) and the Lower Continental Beds (Gundumi Formation and Illo Formation)

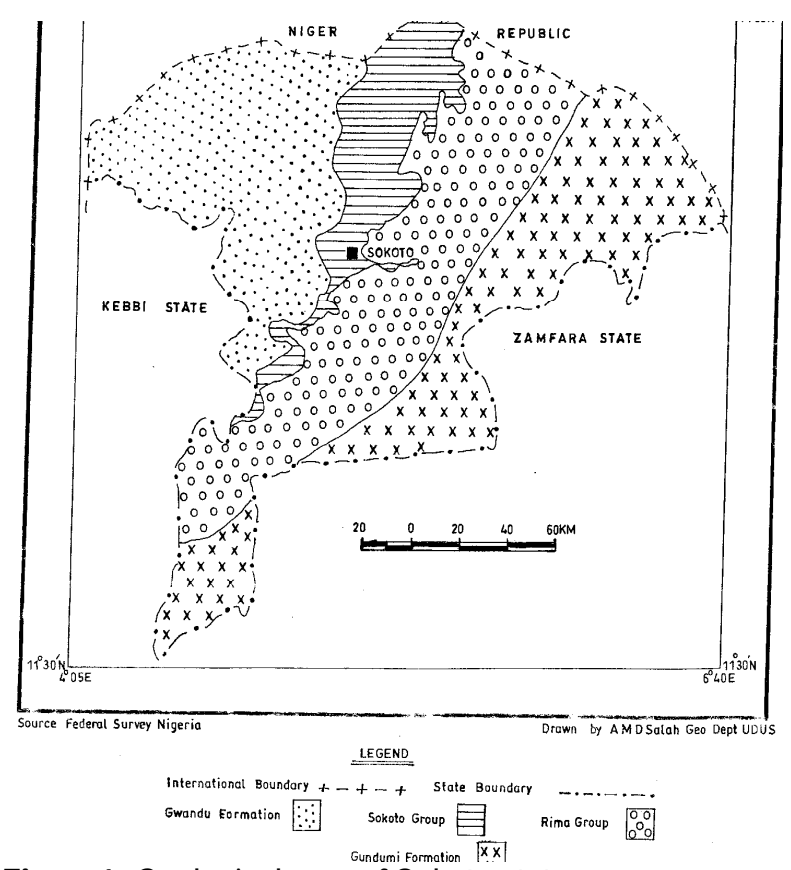

Figure1: Geological map of Sokoto state

Phosphates show features of an epicontinental setting. A unique set of conditions favored the accumulation of phosphates availability of phosphorus in excess of normal in the shallow marine waters, tectonic setting, structural setting and post-depositional history. Deposition of phosphates was in the periods of changing tectonism in the Paleocene (Nwabufo, 2004). The research area (Sokoto city) falls in the Sokoto Group [Paleocene].

\section{MATERIALS AND METHOD Sample Collection and Preparation}

Forty water samples were collected from different location using the stratified random sampling technique. The samples were prepared and analyzed at the Center for Energy Research and Training, Ahmadu Bello University, Zaria, Nigeria.

The sample efficiency, background measurements and plateau test were carried out using standard methods (ASTM, 1995). 


\section{Saidu and Ike: Survey of Gross Alpha Radioactivity in Bore Hole and Well Water in Sokoto City}

$$
\text { Sample efficiency }(\%)=\frac{\text { Weight of Sample }}{\text { Mass of Residue }(0.077 \mathrm{mg})} \times 100
$$

\section{Counting}

The gross alpha counting equipment used in this work was a Eurisys System low Background multiple channel (eight) alpha and beta detector. The equipment is a gas flow proportional counter with $450 \mu \mathrm{g} / \mathrm{cm}^{3}$ thick window of diameter $60 \mathrm{~mm}$. It allows simultaneous counting on eight $300 \mathrm{~mm}$ or $55 \mathrm{~mm}$ diameter samples. Alpha (a) and beta $(\beta)$ activity measurement on compound sources can be selective, sequential or simultaneous. The procedure involves entering the present time, number of cycles and the operational voltage. Also the count characteristics (channel efficiency, and background count rate), volume of sample used and sample efficiency were entered.

\section{Gross alpha counting}

For gross alpha counting, selective measurement was adopted. High voltage of $1650 \mathrm{~V}$ was used, and samples were counted for 5 cycles of $2700 \mathrm{sec}$ per cycle. The alpha count rates as well as alpha activity were calculated using the formula (ISO, 1992).

Count Rate $(\alpha)=\frac{\operatorname{Raw}(\alpha) \text { Count }}{\text { Count Time }}$

$\operatorname{Activity}(a)=\frac{\operatorname{Rate}(a)-\text { Background Count }(a)}{\text { SExCExV }}$

Where: SE = Sample Efficiency; $\mathrm{CE}=$ Chanel Efficiency;

$V=$ Volume of Water Sample

\section{Data presentation \\ Alpha activity}

The alpha activity is expressed as activity concentration $\mathrm{C}$ in Becquerel per liter $(\mathrm{Bq} / \mathrm{L})$. The activity concentration was calculated using the formula (ISO, 1992)

$$
\mathrm{C}=\frac{R_{b-R_{0} \times a_{S} \times m 1.02}}{R_{S-R_{0} \times 1000} \times v}
$$

Where; $R_{b}$ is observed sample count rate $\left(S^{-1}\right)$, Rs is observed standard count rate $\left(\mathrm{S}^{-1}\right), \mathrm{R}_{0}$ is background count rate $\left(\mathrm{S}^{-1}\right), \mathrm{V}$ is volume of sample in liters, and $\mathrm{m}$ is mass in milligrams of ignited residue from volume $\mathrm{V}$. It is important that the factor 1.02 be included in the final equation to correct for the $20 \mathrm{ml}$ of the nitric acid added to the sample as a stabilizer.
Table 1 shows the Alpha background values, channel efficiency and channel Detection Limit of the Eurisys System. The background count rates for alpha particles range from 0.17 to 0.26 mean of $0.23 \mathrm{cpm}$ ). The average efficiencies of the different channels of the detector in alpha only mode is $29.17 \pm 0.15$. The result show that the limit of detection for alpha particles ranges from 0.051 to $0.08 \mathrm{~Bq}$, with an average value of $0.071 \pm 0.02 \mathrm{~Bq}$. The overall result of the preliminary investigation revealed low background, good plateau and low detection.

Table1: Alpha Background Values, Channel Efficiency and Channel Detection Limit of the Eurisys System

\begin{tabular}{cccc}
\hline $\begin{array}{c}\text { Channel } \\
\text { No }\end{array}$ & $\begin{array}{c}\text { Alpha } \\
\text { Background } \\
\text { Values (cpm) }\end{array}$ & $\begin{array}{c}\text { Channel } \\
\text { Efficiency }\end{array}$ & $\begin{array}{c}\text { Detection } \\
\text { Limit }\end{array}$ \\
\hline 1 & 0.259 & 34.84 & 0.081 \\
2 & 0.254 & 33.85 & 0.080 \\
3 & 0.000 & 0.000 & 0.000 \\
4 & 0.250 & 35.64 & 0.076 \\
5 & 0.240 & 38.20 & 0.068 \\
6 & 0.207 & 31.97 & 0.071 \\
7 & 0.000 & 0.000 & 0.000 \\
8 & 0.172 & 36.17 & 0.051 \\
Average & 0.230 & 29.17 & 0.071 \\
\hline * Zero Detections in channels 3and 7 is due to fault of the \\
channels
\end{tabular}

Table 2 shows the gross alpha activity concentration. The range of alpha activity was found to be $0.01 \mathrm{~Bq} / \mathrm{L}$ to $6.00 \mathrm{~Bq} / \mathrm{L}$ with geometric mean of $0.26 \mathrm{~Bq} / \mathrm{L}$. From the result obtained for different places in Sokoto, $75 \%$ of alpha activity is below the contaminant limit of $0.55 \mathrm{~Bq} / \mathrm{L}$ for alpha (USEPA, 1976), while, $25 \%$ of alpha activity is above the contaminant limit. Furthermore only $27.5 \%$ of the alpha activity is below the contaminant limit of $0.5 \mathrm{~Bq} / \mathrm{L}$, as set out by WHO, while $72.5 \%$ of the alpha activity is above the contaminant limit. Comparing the value of alpha activity found in Sokoto with $0.0063 \mathrm{~Bq} / \mathrm{L}$ obtained in Zaria (Onoja, 2004), and $0.0039 \mathrm{~Bq} / \mathrm{L}$ in Kano (Tajudeen, 2006), that of Sokoto is relatively higher. However, the mean alpha activity obtained in Jos $(0.68 \mathrm{~Bq} / \mathrm{L})$ by Habila $(2008)$ is higher.

\section{RESULT AND DISCUSSION}


Table 2: Gross Alpha Activity Concentration (Bq/L) of Water Samples in Sokoto City

\begin{tabular}{|c|c|c|c|c|}
\hline $\mathrm{S} / \mathrm{N}$ & Geo Coordinates & Elevation & Location & Alpha Activity \\
\hline $1^{*}$ & $13.077^{0} \mathrm{~N}, 5.245^{\circ} \mathrm{E}$ & 252 & K/kware & $0.59 \pm 0.08$ \\
\hline 2. & $13.059^{\circ} \mathrm{N}, 5.255^{\circ} \mathrm{E}$ & 276 & Roma & $0.36 \pm 0.14$ \\
\hline 3. & $13.071^{\circ} \mathrm{N}, 5.193^{\circ} \mathrm{E}$ & 242 & Girafshi & $0.37 \pm 0.10$ \\
\hline 4. & $13.068^{\circ} \mathrm{N}, 5.203^{\circ} \mathrm{E}$ & 272 & Gidan Igwai & $0.05 \pm 0.02$ \\
\hline 5. & $13.071^{0} \mathrm{~N}, 5.228^{\circ} \mathrm{E}$ & 251 & Kara & $4.93 \pm 0.33$ \\
\hline 6. & $13.052^{\circ} \mathrm{N}, 5.235^{\circ} \mathrm{E}$ & 294 & Rungumi & $0.50 \pm 0.02$ \\
\hline $7^{\star}$ & $13.065^{\circ} \mathrm{N}, 5.249^{\circ} \mathrm{E}$ & 298 & $\mathrm{~K} /$ marke & $0.05 \pm 0.02$ \\
\hline $8^{*}$ & $13.065^{\circ} \mathrm{N}, 5.215^{\circ} \mathrm{E}$ & 274 & Runjin Sambo & $0.26 \pm 0.12$ \\
\hline 9. & $13.065^{\circ} \mathrm{N}, 5.230^{\circ} \mathrm{E}$ & 294 & Old Market & $0.00 \pm 0.00$ \\
\hline 10. & $13.067^{0} \mathrm{~N}, 5.256^{\circ} \mathrm{E}$ & 284 & K/Rini & $0.20 \pm 0.06$ \\
\hline 11. & $13.060^{\circ} \mathrm{N}, 5.247^{\circ} \mathrm{E}$ & 285 & K/Taramniya & $1.19 \pm 0.26$ \\
\hline 12. & $13.053^{\circ} \mathrm{N}, 5.207^{\circ} \mathrm{E}$ & 260 & Gidan Dare & $2.11 \pm 0.22$ \\
\hline 13. & $13.049^{\circ} \mathrm{N}, 5.230^{\circ} \mathrm{E}$ & 288 & Bello way & $0.09 \pm 0.05$ \\
\hline $14^{*}$ & $13.053^{\circ} \mathrm{N}, 5.245^{\circ} \mathrm{E}$ & 278 & Specialist Hospital. & $0.05 \pm 0.02$ \\
\hline 15. & $13.048^{\circ} \mathrm{N}, 5.252^{\circ} \mathrm{E}$ & 282 & Minannata & $1.10 \pm 0.14$ \\
\hline 16. & $13.047^{\circ} \mathrm{N}, 5.188^{\circ} \mathrm{E}$ & 272 & Kalambaina & $0.28 \pm 0.10$ \\
\hline 17. & $13.047^{\circ} \mathrm{N}, 5.213^{\circ} \mathrm{E}$ & 249 & 5 Star & $0.27 \pm 0.07$ \\
\hline $18^{*}$ & $13.036^{\circ} \mathrm{N}, 5.224^{\circ} \mathrm{E}$ & 287 & Post office & $0.07 \pm 0.02$ \\
\hline $19^{*}$ & $13.039^{\circ} \mathrm{N}, 5.245^{\circ} \mathrm{E}$ & 290 & City Campus & $0.03 \pm 0.02$ \\
\hline $20^{*}$ & $13.046^{\circ} \mathrm{N}, 5.278^{\circ} \mathrm{E}$ & 295 & Gagi & $3.60 \pm 0.34$ \\
\hline 21. & $13.021^{\circ} \mathrm{N}, 5.194^{\circ} \mathrm{E}$ & 277 & Arkilla & $0.24 \pm 0.07$ \\
\hline $22^{*}$ & $13.028^{\circ} \mathrm{N}, 5.220^{\circ} \mathrm{E}$ & 295 & Sokoto guest in & $2.73 \pm 0.23$ \\
\hline $23^{*}$ & $13.029^{\circ} N, 5.238^{\circ} \mathrm{E}$ & 301 & Govt. house & $0.54 \pm 0.08$ \\
\hline $24^{*}$ & $13.046^{\circ} \mathrm{N}, 5.236^{\circ} \mathrm{E}$ & 291 & Sheik Gumi college & $0.01 \pm 0.02$ \\
\hline 25. & $13.031^{\circ} \mathrm{N}, 5.260^{\circ} \mathrm{E}$ & 300 & Mabera & $0.84 \pm 0.10$ \\
\hline 26. & $13.035^{\circ} \mathrm{N}, 5.255^{\circ} \mathrm{E}$ & 298 & Tudunwada & $0.17 \pm 0.06$ \\
\hline 27. & $13.021^{0} \mathrm{~N}, 5.188^{\circ} \mathrm{E}$ & 281 & Sokoto poly & $0.24 \pm 0.02$ \\
\hline 28. & $13.009^{\circ} \mathrm{N}, 5.202^{\circ} \mathrm{E}$ & 282 & Rugar waru & $0.47 \pm 0.08$ \\
\hline $29^{*}$ & $13.019^{\circ} \mathrm{N}, 5.239^{\circ} \mathrm{E}$ & 301 & Usman Faruk Sect. & $0.16 \pm 0.05$ \\
\hline $30^{*}$ & $13.021^{\circ} \mathrm{N}, 5.254^{\circ} \mathrm{E}$ & 297 & Salami & $0.13 \pm 0.06$ \\
\hline 31. & $13.056^{\circ} \mathrm{N}, 5.223^{\circ} \mathrm{E}$ & 285 & Old barrack & $0.04 \pm 0.02$ \\
\hline 32. & $13.013^{\circ} \mathrm{N}, 5.215^{\circ} \mathrm{E}$ & 284 & Police college & $0.52 \pm 0.06$ \\
\hline $33^{*}$ & $13.017^{\circ} \mathrm{N}, 5.226^{\circ} \mathrm{E}$ & 294 & Gwiwa & $0.17 \pm 0.02$ \\
\hline 34. & $13.008^{\circ} \mathrm{N}, 5.254^{\circ} \mathrm{E}$ & 286 & Danbuwa & $0.00 \pm 0.00$ \\
\hline 35. & $12.996^{\circ} \mathrm{N}, 5.199^{\circ} \mathrm{E}$ & 288 & Badonbarade & $6.00 \pm 0.78$ \\
\hline $36^{*}$ & $12.991^{0} \mathrm{~N}, 5.207^{\circ} \mathrm{E}$ & 286 & C.O.E & $0.06 \pm 0.02$ \\
\hline 37. & $12.962^{\circ} \mathrm{N}, 5.200^{\circ} \mathrm{E}$ & 288 & Kasarawa & $0.43 \pm 0.09$ \\
\hline 38. & $12.9^{\circ} \mathrm{N}, 5.209^{\circ} \mathrm{E}$ & 280 & Badon godabe & $0.00 \pm 0.00$ \\
\hline $39^{*}$ & $12.993^{\circ} \mathrm{N}, 5.238^{\circ} \mathrm{E}$ & 305 & Army barrack & $0.02 \pm 0.02$ \\
\hline 40 & $12.983^{\circ} \mathrm{N}, 5.262^{\circ} \mathrm{E}$ & 298 & Kwannawa & $0.64 \pm 0.01$ \\
\hline
\end{tabular}

*Signifies bore hole.

Figure 1 is the distribution of alpha activity and shows few elevated alpha activities. This may be due to the composition of geologic formation of the surveyed area. From Figure 2, it can be seen that the distribution of alpha activity is skewed towards the left. This indicates that most of the areas have low alpha activity.
Figure 3 is a contour Sketch of Gross Alpha Distribution in bore holes and wells in Sokoto city. The lighter the colour of the location the higher the activity. The contour map shows that the areas bounded by longitude 12.983-12.996 and latitude 5.199-5.262 have 
elevated alpha activities of $0.64 \mathrm{~Bq} / \mathrm{L}$ and above. These areas included Badon Barade, Kwannawa and others. A second area of elevated alpha activity includes, Mabera, Gagi and Minannata, which are bounded by longitude 13.031-13.048 and latitude 5.252-5.278. They have alpha activities of $0.84 \mathrm{~Bq} / \mathrm{L}$ and above.

Also areas bounded by longitude 13.071-13.077 and latitude 5.228-5.245 have elevated alpha activities ranging from $0.59 \mathrm{~Bq} / \mathrm{L}$ to $4.93 \mathrm{~B} / \mathrm{L}$. These areas comprise K/Kware, Kara etc. Sokoto Guest Inn, Govt. House and environs bounded by longitude13.02813.029 and latitude 5.220-5.238 are also areas with elevated alpha activities of $0.55 \mathrm{~Bq} / \mathrm{L}$ and above. Other areas of high alpha activities include, Gidan Dare and K/Taramniya, bounded by longitude and latitude 13.053, 5.207 and 13.060, 5.247 respectively. The remaining areas are of low alpha activities.

\section{Alpha}

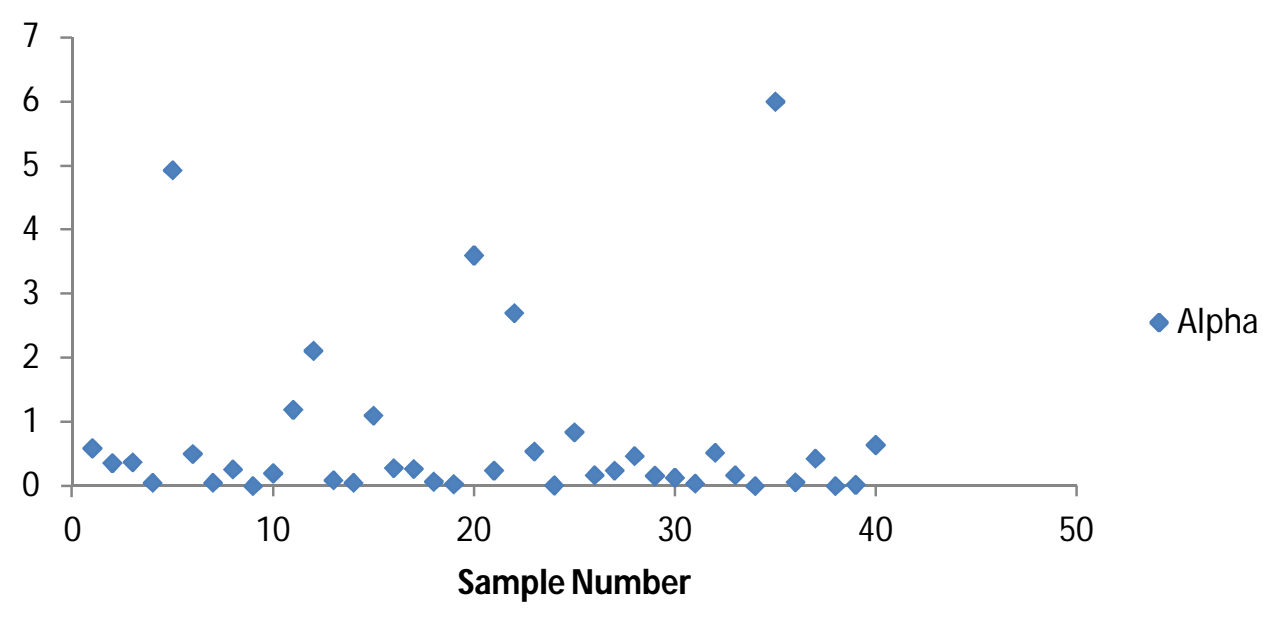

Figure 1: Alpha Activity in Water in Sokoto City

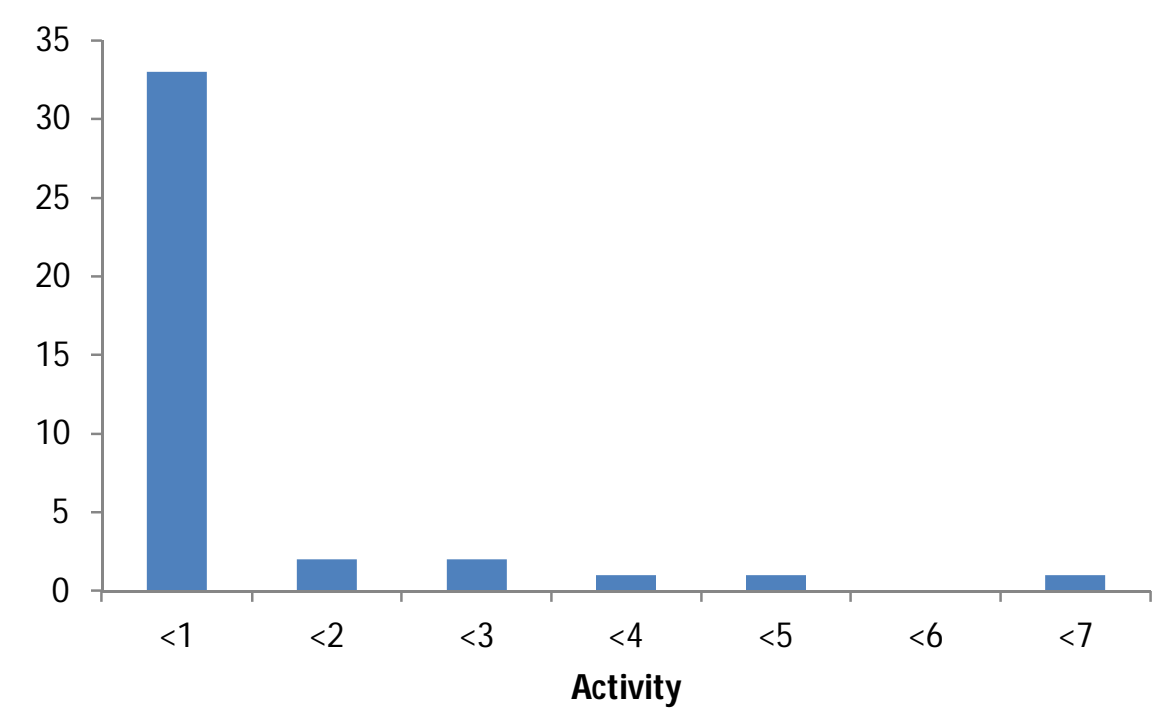

Figure 2: Distribution of Alpha Activity in Sokoto City 


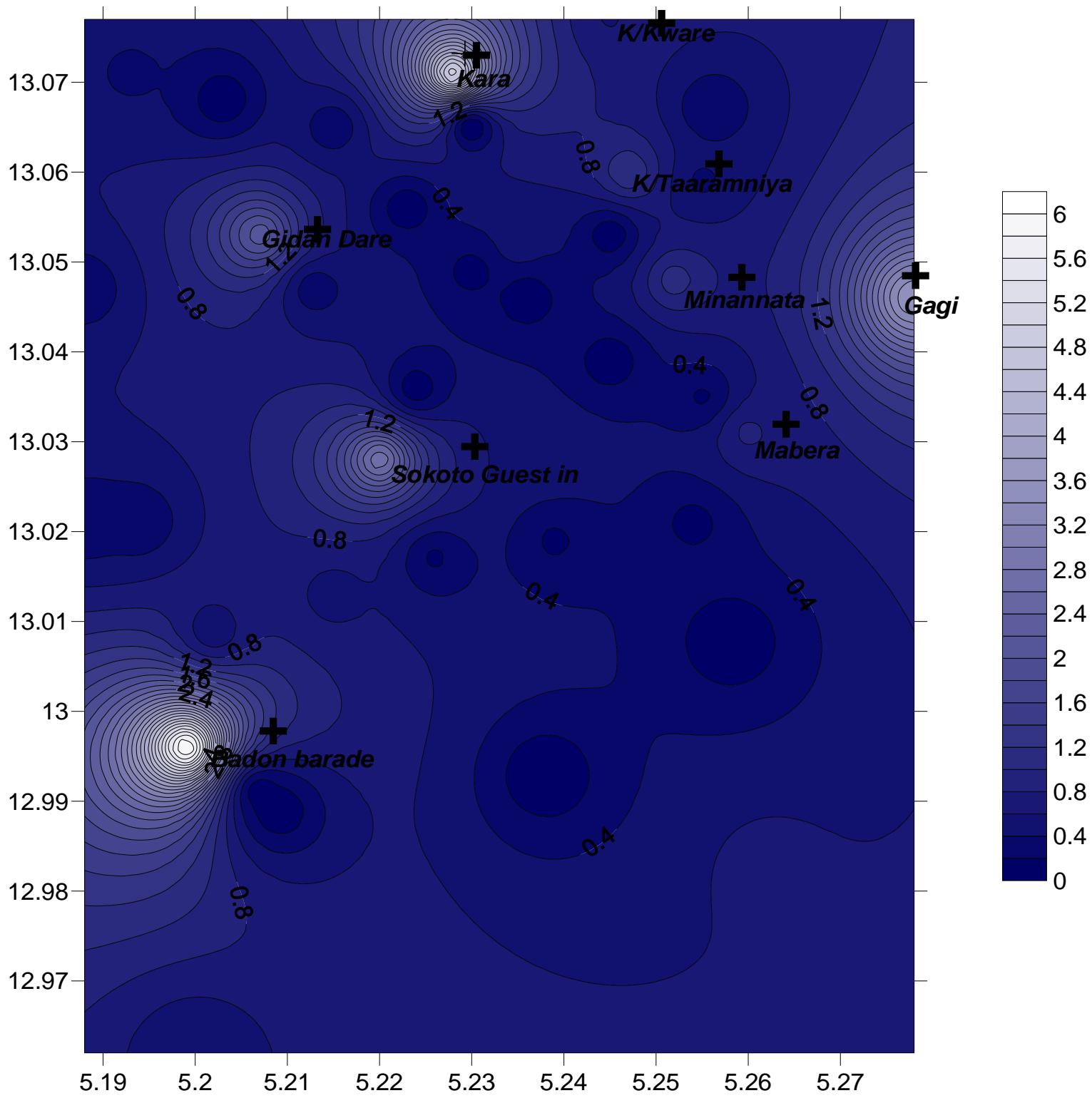

Figure 3: Contour Sketch of Gross Alpha Distribution in Bore Holes and Wells in Sokoto city

\section{CONCLUSION}

It may be concluded that while water from some boreholes and wells in Sokoto meet the recommendations of the USEPA and WHO, some do not meet the USEPA and WHO standard. Therefore, there is the need for determination of radionuclides responsible for the high activity concentration in the water of the affected areas.

\section{REFERENCES}

ASTM, (1995).Standard test method for alpha particle radioactivity of water. ASTM D1943-90 and D1890-90
Avwiry, G.O. and Agbalagba, E.O. (2007). Survey of Gross Alpha and Beta Radionuclide Activity in Okpare-Creek Delta State Nigeria. Journal of Applied Sciences, 7(22): 3542-3546.

Brassard, P.G. (1996). Wetland and Water Pollution. Boston College of Environment. Aff. Law Review.Vol.23.number4 pp885-919.

Daniel E. (2006). Investing in Tomorrow's Liquid Gold. (USEPA)

Habila N. (2008). Survey of Gross Alpha and Beta Radioactivity in Jos City. M.sc thesis, University of Jos, Nigeria (Unpublished). 


\section{Saidu and Ike: Survey of Gross Alpha Radioactivity in Bore Hole and Well Water in Sokoto City}

ISO (1992) International Organization on Standardization.(1992). Water Quality Measurement of Gross Alpha Activity in Non Saline Water, Thick Source Method, ISO (96961992revised). Geneva, Switzerland.

Kozinski D.H. (1995). Natural Radioactivity and Inorganic chemistry of Ground Water in the Kirkwood-Cohansey Aquifer System, Southern New Jersey. U.S Geological Survey Water Investigation Reports 92-41

Krantz D. and Kifferstein B.(2008); Water Pollution and Society [Online] available at www.Wikipedia the free encyclopedia (accessed 23 ${ }^{\text {rd }}$ Feb., 2010).

Larry, W. (2006). "World Water Day: A Billion People Worldwide Lack Safe Drinking Water" [online] available at www.environment.about.com (accessed: 23 $3^{\text {rd }}$ February, 2010).

NBSN (2010) National Bureau of Statistics Nigeria; 2006 population census result (the federal republic of Nigeria - Sokoto administrative unit) [Online] available at www.xist.org. (accessed: $14^{\text {th }}$ June, 2009)

NCRP (1989) National Council on Radiation protection, report number 97, Measurement of Radon and Radon Daughters in Air.NCRP. Washington.
Nwabufo K.E. (2004). Moments and industrial development in Sokoto state, Nigeria. Special paper for the investment retreat, Sokoto state Nigeria, $18 p$

Onoja, R.A. (2004). Survey of Gross Alpha and Beta Radioactivity in Wells from Zaria. M.Sc. thesis A.B.U.Zaria.

Otton, J.K. (1994). Natural radioactivity in the Environment [Online] available at www.energy.usgs.gov (accessed: 10 ${ }^{\text {th }}$ February, 2010).

Tajudeen H.V. (2006). Survey of Radioactivity in Wells and Bore holes from Gwammaja Area of Kano City. (Unpublished M.Sc. Thesis), A.B.U.Zaria.

USEPA (1976). United State Environmental Protection Agency. National Primary Drinking Water Regulations. Agency Report EPa-570/9-76-003.

USEPA (1996). United State Environmental Protection Agency. Prescribed Procedures for measurement of radioactivity in drinking water. Environmental Monitoring and Support Laboratory.EPA. 600/480- 032

WHO (2006). World Health Organization, Guidance for Drinking Water Quality.2 ${ }^{\text {nd }}$ Edition. Pp197-209.

WHO (2008). World Health Organization, Guidance for Drinking Water Quality. 3 $3^{\text {rd }}$ Edition. .pp197-209. 